\title{
THE ARGUMENT ON A STUDENT' THESIS OF DEPARTMENT OF ISLAMIC EDUCATION
}

\author{
Dheka Dwi Agustiningsih \\ Andalusia Neneng Permatasari \\ Alhamuddin \\ Bandung Islamic University \\ ddagusti@unisba.ac.id
}

First draft received: 310ctober 2016

Final proof received: 22 February 2017

Abstract
This paper discusses the arguments found in a student' academic writing, namely a thesis. It attempts to
show how an argument is built in a student's thesis in the Department of Islamic Education, Faculty of
Tarbiyah and Education, Islamic University of Bandung by drawing upon the theory of Toulmin (2003).
The results of this research show that verse, hadith, and exegesis become the starting point of the
argument to be presented in the thesis. However, there is a discrepancy between the verses used as
warrant's claim and the data on the student's thesis. Consequently, the argument becomes unstable
because of the inconsistencies of argument elements. The implication of this research is concerned with
the supervision process of a student's thesis that should give more emphasis on how the student makes
his or her arguments correctly.
Keywords: argument; paper; claim; data; warrant
To cite this paper (in APA style):
Agustiningsih, D. D., Permatasari, A. N., Alhamuddin. (2017). The argument on a student' thesis of
department of Islamic education. International Journal of Education, 9(2), 133-138 doi:
dx.doi.org/10.17509/ije.v9i2.5477

\section{INTRODUCTION}

A paper is identical with final assignment of students in bachelor degree. In the department of Education of Islamic Religion (PAI), Faculty of Tarbiyah and Education, Islamic University of Bandung (UNISBA), thesis is a scientific writing that becomes one of the requirements for finishing the study.

The paper is one of the media in doing research activity that is done by the students. This is related to Regulation of Education and Culture Ministry of the Republic of Indonesia Number 49, years 2014 about the Standardization of National Education, article 45 sentence 4

Writing the thesis in the Department of Islamic Education can be conducted by the students who have fulfilled the requirements in the last semester. The requirements are at least passing 130 credits of the subjects; passing the Methodology subject, Research I, and II subjects; contracting the final thesis subject (proven by a printed Planning Study Form (Indonesian FRS); paying the administration fee; and sending the thesis proposal to the paper biro. These requirements were made considering the standard quality based on the regulation of Ministry of Education and Culture number 49, years 2014, article 45 , sentence 3 .

The number of semester credit (SKS) and taken subjects is supposed to have a relation to the thesis that will be written down. Along with the support of sufficient knowledge, the process of research and writing is expected to help students acquire competent qualification. The writing of the thesis should lead to fulfilling the learning achievement of graduates (Regulation of Ministry of Education and Culture number 49 , year 2014, article 45 , sentence 4).

A bachelor is supposed to be able to represent their own argument. Presenting the argument well indicates the ability of critical and logical thinking. Argument, according to Adian and Pratama (2015), is the series of sentences, statements, or propositions, that have unified among each other. As an academic writing, the thesis can be seen as a media to show the students' arguments about certain things that become an index of their degree.

A number of studies have been conducted in analyzing the academic papers. Puspidalia (2015), using Toulmin's reasoning model has studied the academic papers written by some lecturers for the accredited journal of Al-Tahrir. The research showed that there are two patterns of reasoning, inductive and deductive, but deductive reasoning pattern is more dominant. In addition, it is also identified the error of reasoning due to the improper relationship or relevance and the fault analogy. The elements most widely used are the claim and ground. There is also a writer who filed a claim in the form of a chain argument without sufficient reasons so that the argument is unclear.

The study of the papers at the secondary level has also been done by Syaifudin and Utami (2011) and Narimo, et al (2015). Syaifudin and Utami (2011) examined the arguments of students in writing argumentative discourse which is the assignment document of students using analytical models of Holsti (1969) with the analysis procedure of Miles and 
Huberman (1994). The results of the research conducted showed there is relatively complete use of the elements of argument, so the argument is clear. These results are also shown by the research conducted by Narimo (2015). In his study about propositions and arguments in class discussion of grade eight at SMP Negeri 1 Watulimo, Trenggalek, East Java Province, using the theory of Latsko and argumentation of Toulmin, his research showed that there are two patterns of propositions used, affirmation and negation, while the argument used is a collaborative argument, i.e. the argument built by the students together with the structure of simple and complex argument with the complete elements.

In addition to the above studies that make writing academic of lecturers and students as the objects of study, there is also a study on books done by Dilianza, Siregar, and Kusmara (2015). They examined the application of theoretical argument in a book entitled Five Maestros of Indonesian Modern Art. This study used the theory of the argument formation of Toulmin, where it takes some elements such as data, claim, warrant, backing, qualifier, and rebuttal. This study shows that the arguments contained in the paper are not presented methodologically and the claim is not parallel to the claims contained in other literatures and basing the argument on the assumption of the author of the book. The results of this study showed the similar results to the study conducted by Puspidalia (2015) that indicate that the high academic qualification is not directly proportional to the clarity of argument conveyed.

It can be inferred that the results of research conducted by Narimo, et al (2015) and Syaifudin and Utami (2011) show the result of which is inversely proportional to the results of research conducted by Puspidalia (2015) and Dilianza, Siregar, Kusmara (2015). The arguments contained in the students' paper and discussions are considered strong because they contain the elements of the argument as proposed by Toulmin, compared to the arguments developed by the authors who work as lecturer.

The attention to argue capability also includes the use of argument as a learning model as practiced by Fahim and Hashtroodi (2012). Fahim and Hashtroodi (2012) examined the argument ability of Iranian students (average age of 21 years) who took the English Study Program with the translation specification at the University of Azad. The object of study is relevant to the research conducted by the writer, which is the ability to write an argumentative text on the same level, university. The research result indicates that the model of Critical Thinking which is tested to develop the ability of writing argumentative essay in four meetings can improve the ability of students, although it is not significant.

The study of the argument is not limited to academic papers. Some studies show that the arguments can be found in every kind of discourse. The argument in the discourse of persuasion is as disclosed by Nurusyifa (2011), the arguments in the discourse of the argument as practiced by Winahyu (2011), and the arguments in the discourse of the narrative as disclosed by Zaimar (1997), Patton (2003), and Permatasari (2012).

In particular, with regard to the above studies, through this article, the writer reports on a study of the arguments of a student' thesis of Islamic Religion
Education, Faculty of Tarbiyah and Education, Islamic University of Bandung. A thesis as an academic writing that shows the final results of study a bachelor student is supposed to demonstrate the ability of analysis and synthesize. It is as stated by Adian and Pratt (2015) that thinking should be orderly. By using the theoretical argument offered by Toulmin (2003), the form and structure of the argument in the thesis are analyzed.

\section{Proposition and Argument}

In analyzing the form of argument there are two devices that can be used as an analysis tool, namely the proposition and argument elements. Larson (1984) stated that the proposition is a semantic unit consisting of concepts: the first is the core concept and other concepts that are more directly related to the concept of a core made of the concept of objects, events, and attributes. For example, if the core concept is an event, then the proposition is called the incident proposition. To mark the first proposition of the incident, conduct a search incident concept in the form of the verb. After it is done, then search for the participants, the persons or things that do or are attached with the job. Then, do the preparation of the proposition by chronology.

The proposition in a text is associated with other propositions through communication links. Larson (1984) mentioned the proposition that plays more important roles is marked with a capital letter. These propositions relationships are as follows: (1) Addition Relationships and Supporting Relationships are the relationships that the proposition is connected to one another by their times; (2) Explanation Relationship is an explanation with clarification of returned disclosure and vice versa; (3) Logical Relationships always contains a concept or idea of causation; (4) Stimulusresponse Relationship is only found in the discourse of speech and conversation (dialogue).

In this study, the analysis of the relationship is done before conducting a study on the structure of the argument. The relationship of propositions serves to look at each element of the chapter in the thesis that is interrelated. In addition, by observing the relationship between propositions, it can be seen the part of the central state or event which is the main proposition. This main proposition will be drawn to search for arguments.

The argument, according to Toulmin (2003), has its own structures just like organisms. The structure is what will determine the level of validity of an argument. There are two models in the way of thinking (logic), the mathematical logic and the logic of the law.

Speaking of the argument is not to be separated from the classical idea of Aristotle that the argument is made up of the major premise, minor premise. and a conclusion which is then referred to as mathematical logic. However, further doubts raise about the ability of the major premise, minor premise, and a conclusion in accommodating all elements of the argument. In daily life, the three main things cannot accommodate all the elements of argument.

This mathematical logical doubt will find the path of light in the presence of the legal logic (Toulmin, 2003). The law of the logic means the decisionmaking process generally used in the trial. The decision process does not present truth for granted, but needs to be fought four. Therefore, their claims 
(major premise) and data (minor premise) alone do not guarantee the truth. In fact, there are circumstances that refuse, stipulate, or even reinforce claims that escape from mathematical logic thinking.

Walton (2006) defined the argument as the opinion to support or criticize the existing statement. Opinion or reason is the main core of the argument. From the opinion, it can be seen whether the arguments for a declaration exist or not, because, like what Toulmin said (2003), every act of expression always contains the true claims (C). This true claim may contain support or refutation.

Claim is a statement that is believed by the writer or speaker. In a process of expressing opinions, whether oral or written, claims will always be maintained by the speaker or writer. Efforts to clarify and defend this claim will be successful if it is supported by the data (D) or a firm foundation, in the form of evidence to substantiate the claim. If the existing evidence is insufficient as the data to support the claim, there is the assurance (warrant (W)) as supporting evidence. Therefore, Toulmin (2003) explained that a statement that may contain data and warrants as well. With the claim (C), the data (D), and the warrant $(\mathrm{W})$, it can be said that the argument has been structured well. The qualifier $(Q)$ and rebuttal $(\mathrm{R})$ will arise at the moment the situation requires. The other part that is introduced by Toulmin (2003) is backing (B) which serves to support the warrant (W), the part that argument can establish patterns of C-DW-B-Q-R or can only consist of C-D, which is a claim with one or more of data.

\section{METHOD}

The study uses a qualitative approach with the case study method. In this context, the writer takes the case of how the arguments are made in the student's thesis of Faculty of Tarbiyah and Education, Education of Islamic Religion Department in 2015 with a cum laude graduate, entitled. The selection is based on the assumption that the consideredperfect-thesis should make the arguments well.

Data analysis in this research were conducted in two stages. First, the proposition was analyzed based on the theory of Larson (1984). It is to see: (i) the propositions that make up each chapter in the thesis and (ii) the type of relationships between propositions. Second, the main proposition was used for arguments contained in the academic writing by using the theory of Toulmin (2003).

\section{Arguments on the Thesis}

Based on the analysis, this thesis consists of 176 propositions. From the 176 propositions, it was found that there were fourteen prominent (main) propositions. However, not all the propositions contained in the thesis have a logical relationship. In this thesis, there are only three propositions that have a logical relationship.

Propositions that have the logical relationship are used to determine the form of arguments of the thesis. As stated by Toulmin (2003) argument is at least structured by claim (claim) and data (data), and the argument is seen as a good one if the relationship between claim and data is supported by the warrants (C-D-W). To add the supporting arguments, Toulmin (2003) adds support/backing and opponents/rebuttal (C-D-W-B-R). In analyzing the argument form of the thesis, there is the pattern of C-D-W (claim, data, and the guarantor/warrant).

In this thesis, there are two parts of the argument. The first argument can be seen below:

Data 1 (1) The existing legal system does not
provide sufficient protection to the
victim role.
Data 2 legal system in Indonesia
(2) The lotection
does not guarantee the protections
of victims of violence in the scope
of the household.

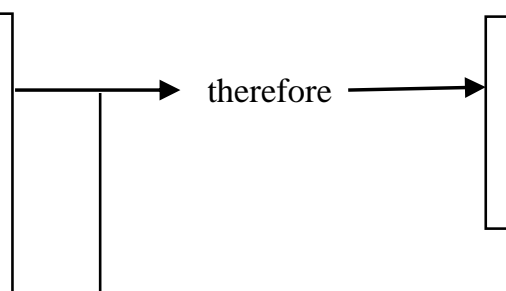

Claim

Irony on the nature of household establishment.

because

Warrant

1) The role of the husband as head of the family.

2) Husbands should imitate the behavior of the Prophet Muhammad.

3) The task is for men to lead women.

4) The advantage given by God to man is the ability to make a living.

Chart argument number 1

Irony of the nature of household establishment

In this argument, the claim is the irony of the nature of household. As stated by Tolumin (2003), claims need to be defined and maintained by presenting support in the form of data (D) or a firm foundation. The data offered or proposed by the writer are twofold. The first datum is the existing legal 
system does not provide the sufficient protection to the victim role. The second datum is the legal system in Indonesia does not guarantee the protection of victims of violence in the scope of the household.

To check for a fit between the data and claim, Toulmin (2003) offers a conjunction because, between the claim and the data, to demonstrate their logical relationship, i.e. causality. The relationship between the first data and claims in this argument is that irony of the nature of household is due to the existing legal system that does not provide sufficient protection to the victim role. The relationship between the second data with claims that irony of the nature of household is due to the legal system in Indonesia does not guarantee the protection of victims of violence in the scope of the household.

Having considered the data and claim that form the causality, the writer tries to present a guarantor (warrant) in the form of commentary verses of the Quran. Guarantor is presented is as follows.

1) The role of the husband as head of the family.

2) The husband should imitate the behavior of the Prophet Muhammad.

3) The task is for men to lead women.

4) The advantage afforded by God to humankind is the ability to provide a livelihood.

Semantic logic that is used to identify the consistency between the claims, data, and a warrant is to add a conjunction. Nevertheless, it is found that the first claim arises because the warrant appears first. It is not the data that underlie the appearing claim. Seeing the relationship between propositions of prominent, the chart is drawn as follows.

\footnotetext{
Warrant

1. The role of the husband as head of the family.

2. Husbands should imitate the behavior of the Prophet Muhammad.

3. The task is to lead men to women.

4. The advantage given by God to man is the ability to make a living.
}

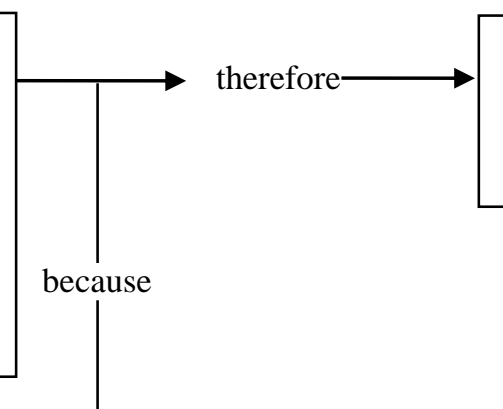

\section{Claim}

Irony on the nature of household establishment.

Data 1

(1) The existing legal system does not provide sufficient protection to the victim role.

Data 2

(2) The legal system in Indonesia does not guarantee the protection of victims of violence in the scope of the household.

Chart argument number 2

Irony of the nature of household establishment

An exegesis that is used as warrants underlies the emergence of the claim, which is stated as an irony on the nature of the household. Everything that is ideal in the holy verses underlies the claim. The claim uttered is matched with the data about the reality of the legal system in Indonesia.

\begin{tabular}{|c|c|c|}
\hline Data & & Claim \\
\hline $\begin{array}{l}\text { Women change the habits before the } \\
\text { marriage for the fulfillment of the husband } \\
\text { right }\end{array}$ & 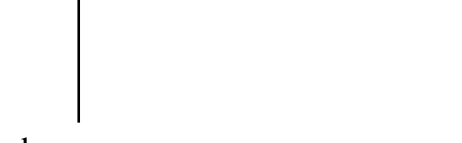 & $\begin{array}{l}\text { This implication as a } \\
\text { form of sacrifice of a } \\
\text { woman. }\end{array}$ \\
\hline
\end{tabular}

\section{Warrant}

1. Husbands do not seek-out his wife fault who is obedient to him.

2. All the mistakes do not inflict to wife.

3. Husband should find out the reason angry wife.

The implication as a form of sacrifice of a woman 
The second claim expressed is this implication is as a form of sacrifice of a woman. A claim based on data that offer the phenomenon that women change the habit before marriage is a sort of fulfillment of the husband's right. The relationships between claim and the data is bound by the rise of the guarantor/warrant, that is the exegesis of the AlQuran surah An-Nisa (verse 34: 1) the husband should not find the fault of the wife who has been obedient to her; 2) All the mistakes do not inflict to wife; and 3) the husband should find out why his wife is angry.

Basically, to form a logical relationship, the warrant should be able to embrace the claim and the data as a whole. In the offered argument, the warrant does not have conformity between the meaning component with the claim and data. In order to strengthen the claim and the data, the warrants should have compatibility with the context of the fulfillment of rights by the husband and wife and the sacrifice of a woman. However, warrants are selected to precisely describe the things that should have been done by the husband.

Based on analysis of the arguments on the students' thesis of Islamic Education Department, Faculty of Tarbiyah and Education, Islamic University of Bandung, it was found that the materials of the data and guarantor is inconsistent with the argument concept of Toulmin (2003). In analyzing the thesis, the data used by the writer is in the form of verses of the Quran, al-Quran and hadith exegesis. However, according to Toulmin (2003) verses of the Quran and hadith exegesis is a material that can be used as a guarantor. Data, according to Toulmin (2003), is the evidence to strengthen, underlie, and cause the emergence of the claim. In the context of the thesis writing, it can be in the form of research, statistics, and scientific publications.

Furthermore, the present study shows that the arguments at the university level which is built by the students of religious studies of Islam are constructed by elements of claim and guarantor. This finding is in line with the findings of Puspidalia (2015) regarding the most widely used elements in arguments.

Puspidalia's research results (2015) also concur with the present research's in that the claim is not supported by the data, but by other elements. Puspidalia (2015) also found that that there is no sufficient reason in the claim chain, so that the argument is not clear, and the findings of this study also show that the proposed claim does not have enough data.

In addition, it is also found that the claim that is put forward in the thesis is based on the verse and the interpretation of the Koran. This finding shares some similarities with the research results of Dilianza, Siregar, Kusmara (2015) in which the claims are based on the authors' assumption.

\section{CONCLUSIONS}

In the framework of the research activities of students, thesis is a work that can show the scientific knowledge, scientific thinking processes, and critical attitude. Therefore, students are required to present the results of their thinking in a systematic, structured, and logical writing.
The study of the students' thesis of Islamic Education Department, Faculty of Tarbiyah and Education, Islamic University of Bandung indicates that the propositions that are used by the writer of the thesis do not have a relationship with the topic. Moreover, the verses of al-Quran and hadith are used as a starting point for the argument to be conveyed through thesis. It shows that the study of a verse has not been elaborated well as part of scientific work. There is a discrepancy between verses written as warrants/guarantor for claim and data on that thesis. There is also a warrant that obscures the logical relationships built by claim and data. Consequently, the uttered argument becomes unstable because of the inconsistencies between argument elements.

There are still some steps that can be done to complete this study. Further research that can be done is on the thesis of the Religious Education Faculty students in elaborating, affirming, comparing, or negating a verse, hadith, and exegesis as a part of scientific work.

\section{REFERENCES}

Adian, D. G. \& Pratama, H. S. (2015). Teknik Berargumentasi. Jakarta: Kencana.

Dilianza, Ahmad, Y, Siregar, A. T. H., \& Kusmara, A. R. (2015). Penerapan Teori Argumen dalam Penulisan Seni Rupa; Kasus: Buku Lima Maestro Seni Rupa Modern Indonesia. Jurnal Tingkat Sarjana Bidang Seni Rupa, 4, 1-7. Retrieved from http://jusnals1fsrd.itb.ac.id/index.php/visualart/article/view/551.

Fahim, Mansoor, \& Hashtroodi, P. (2012). The Effect of Critical Thinking on Developing Argumentative Essays by Iranian EFL University Students. Journal of Language Teaching and Research, 3(4), 632-642. https://doi.org/10.4304/jltr.3.4.632-638

Holsti, O. (1969). Content analysis for the social sciences and humanities. Massachusetts: Addison Wesly Publishing Company.

Larson, D. M. (1984). Penerjemahan Berdasarkan Makna: Pedoman untuk Pemadanan Bahasa. Trans. Kencanawati Taniran(1999). Jakarta: Penerbit Acan.

Miles, M. N. \& A.M. Huberman. (1994). Qualitative data analysis: A source book of new methods. Beverly Hills: Sage Publication.

Narimo, Santosa, A., Pratiwi, Y., \& Mujianto. (2015). Proposisi dan Argumen dalam Diskusi Kelas Siswa SMP, Jurnal Pendidikan Humaniora, 3(4), 276-286. Retrieved from http://journal.um.ac.id/index.php/jphpISSN.

Nurusyifa. (2011). Argumen dalam ceramah motivasi Mario Teguh "Golden Ways (Unpublished thesis). Universitas Indonesia, Depok.

Patton, M. D. (2004). Frauds, hoaxes and pseudoscience: A Course in Argumentation. Academic Exchange Quarterly, 7(4), 204-208

Permatasari, A. N. (2012). Argumen dalam narasi: Analisis struktur wacana tulisan samuel mulia pada rubrik parodi Kompas Minggu. Universitas Indonesia, Depok.

Regulation of the Ministry of National Education Number 49 Year 2014 regarding National 
Standards for Higher Education. Jakarta: Kemendikbud.

Puspidalia, Y. Sova. (2015). Argumen dalam karya ilmiah dosen pada jurnal terakreditasi Al-Tahrir STAIN Ponorogo berdasarkan teori penalaran model Toulmin, Widya Warta, 39, 285-296. Retrieved from http://portal.widyamandala.ac.id/jurnal/index.php /warta/article/view/309/298.

Rahayu, S. (2015). Implikasi Pendidikan QS An-Nisa Ayat 34 tentang bagaimana sikap suami terhadap isteri di kala terjadi perselisihan. (Unpublished Bachelor's Thesis). Universitas Islam Bandung, Indonesia.

Syaifudin, A. \& Utami, S. P. (2011). Penalaran argumen siswa dalam wacana tulis argumentatif sebagai upaya membudayakan berpikir kritis di
SMA. Lingua Jurnal Bahasa dan Sastra, 7, 6576. Retrieved from http://juornal.unnes.ac.id/artikelnju/lingua/868.

Toulmin, S. (2003). The Uses of Argument. Cambridge: Cambridge University Press. https://doi.org/10.1017/CBO9780511840005

Walton, D. (2006). Fundamental of Critical Argumentation. Cambridge: Cambridge University Press.

Winahyu, S. K. (2011). Argumen dalam Opini Majalah Tempo (Unpublished Thesis). Universitas Indonesia, Depok.

Zaimar, O. K. S. (1997). Argumentasi dalam Cucu Wisnusarman Karya Parakitri: Suatu kajian semiotik. Research Report. Jakarta: Fakultas Sastra UI. 